\title{
Mercury content in the fur of jaguars (Panthera onca) from two areas under different levels of gold mining impact in the Brazilian Pantanal
}

\author{
JOARES A. MAY JÚNIOR ${ }^{1,2,3}$, HOWARD QUIGLEY ${ }^{4}$, RAFAEL HOOGESTEIJN ${ }^{4}$, \\ FERNANDO R. TORTATO ${ }^{4}$, ALLISON DEVLIN ${ }^{4,5}$, RUI M. DE CARVALHO JÚNIOR ${ }^{6}$, \\ RONALDO G. MORATO ${ }^{2,7}$, LEONARDO R. SARTORELLO ${ }^{3}$, LILIAN E. RAMPIM $^{3}$, \\ MARIO HABERFELD ${ }^{3}$, ROGÉRIO C. DE PAULA ${ }^{2,7}$ and JAIRO JOSÉ ZOCCHE ${ }^{8}$
}

\author{
${ }^{1}$ Hospital Veterinário Universitário, Universidade do Sul de Santa Catarina/UNISUL, Av. \\ José Acácio Moreira, 787, Bairro Dehon, 88704-900 Tubarão, SC, Brazil \\ ${ }^{2}$ Instituto Para a Conservação dos Carnívoros Neotropicais (Pro-Carnívoros), Av. Horácio \\ Neto, 1020, Parque Edmundo Zanoni, 12945-010 Atibaia, SP, Brazil \\ ${ }^{3}$ Projeto Onçafari, Av. Pedroso de Moraes, 1553, Bairro Pinheiros, 05419-001 São Paulo, SP, Brazil \\ ${ }^{4}$ Panthera, 8 West $40^{\text {th }}$ Street, $18^{\text {th }}$ floor, 10018 , New York, NY, USA \\ ${ }^{5}$ State University of New York College of Environmental Science and Forestry, 1 Forestry Drive, 13210, Syracuse, NY, USA \\ ${ }^{6}$ Laboratório de Espectrometria de Massa/LEMA, 211/207, Universidade Federal de Santa Catarina/ \\ UFSC, Campus Trindade, Bairro Trindade, 88040-900 Florianópolis, SC, Brazil \\ ${ }^{7}$ Centro Nacional de Pesquisa e Conservação de Mamíferos Carnívoros/CENAP, Instituto Chico Mendes de \\ Conservação da Biodiversidade/ICMBio, Rod. Hisaichi Takebayashi, 8600, 12952-011 Atibaia, SP, Brazil \\ ${ }^{8}$ Programa de Pós-Graduação em Ciências Ambientais, Laboratório de Ecologia de Paisagem e de Vertebrados, Universidade \\ do Extremo Sul Catarinense/UNESC, Av. Universitária, 1105, Bairro Universitário, 88806-000 Criciúma, SC, Brazil
}

Manuscript received on March 15, 2017; accepted for publication on May 15, 2017

\begin{abstract}
The Pantanal is the largest inland wetland in the world and is under increasing anthropogenic threats, including long-term regionally intensive gold mining practices. Gold mining activities are known to cause the release of harmful pollutants such as mercury $(\mathrm{Hg})$ to the surrounding environment. Jaguars (Panthera onca (Linnaeus, 1758)) are apex predators, and therefore show great potential to accumulate $\mathrm{Hg}$ by biomagnification. We hypothesize that total $\mathrm{Hg}$ content in the fur of jaguars from two sites within the Brazilian Pantanal would be significantly different as a function of distance from active gold mining operations. The $\mathrm{Hg}$ content was determined by fluorescence spectrometry. The mean $\pm \mathrm{SD} \mathrm{Hg}$ content in jaguars from the study site influenced by gold mining (SB) was compared to jaguars sampled in the area free of gold mining activities (CA) using a one-way ANOVA. The mean $\mathrm{Hg}$ content in jaguars from SB $\left(673.0 \pm 916.8 \mu \mathrm{g} \mathrm{g}^{-1}\right)$ is significantly different from jaguars sampled in CA $\left(29.7 \pm 23.3 \mu \mathrm{g} \mathrm{g}^{-1}\right), \mathrm{p}=0.03$. The maximum recorded content of $\mathrm{Hg}$ was 2,010.4 $\pm 150.5 \mu \mathrm{g} \mathrm{g}{ }^{-1}$, highest level ever recorded in a wild animal. The data indicate that $\mathrm{Hg}$ is an important threat to jaguars within at-risk regions of the Pantanal.
\end{abstract}

Key words: biomagnification, heavy metals, mammal, wetland.

\footnotetext{
Correspondence to: Jairo José Zocche

E-mail: jjz@unesc.net

* Contribution to the centenary of the Brazilian Academy of

Sciences.
} 


\section{INTRODUCTION}

Mercury $(\mathrm{Hg})$ is a rare element found in deposits within the earth's crust, with significant environmental distribution due to anthropogenic activities such as mining (Ehrlich and Newman 2008, Kirby et al. 2013). The wide-spread use of $\mathrm{Hg}$ in intensive gold mining practices transforms the surrounding environments into pollution hotspots (Vieira et al. 2011). Most forms of $\mathrm{Hg}$ are toxic to biotic life (Lacerda and Fitzgerald 2001, Risher et al. 2002), and methylmercury (MeHg) is neurotoxic (Leady and Gottgens 2001, Risher et al. 2002, Akira et al. 2004). For organisms, the primary route of entry of organic $\mathrm{Hg}$ is the ingestion of MeHg-contaminated food (Callil and Junk 2001, Risher et al. 2002), although the ingestion of $\mathrm{MeHg}$-contaminated water may be another significant contributor.

The presence of $\mathrm{Hg}$ in the environment affects species within the food chain through the processes of bioaccumulation and biomagnification, as the pollutants accumulate in tissues of organisms and are made biologically available (Gutleb et al. 1997, Callil and Junk 2001). MeHg is typically found in higher concentrations in adult fishes and in larger, long-lived predators of aquatic organisms (Callil and Junk 2001, Risher et al. 2002, Chan et al. 2003, Fonseca et al. 2005). In mammals, $\mathrm{MeHg}$ is rapidly absorbed through the gastrointestinal tract and over time is redistributed to other organs and body parts, including fur (Wobeser and Swift 1976, Wobeser et al. 1976, Akira et al. 2004, Nuttall 2006). High concentrations of $\mathrm{Hg}$ has been documented in several free-living mammalian species, including: Lutra canadensis (Wren 1985, Wren et al. 1986, Halbrook et al. 1994, Evans et al. 1998, 2000, Yates et al. 2005, Sleeman et al. 2010); Lutra lutra (Mason 1988, Mason and Madsen 1992, Hyvärinen et al. 2003); Mustela vison (Wobeser et al. 1976, Evans et al. 2000, Yates et al. 2005); Neovison vison (Wobeser et al. 1976, Basu et al.
2007); Puma concolor coryi (Roelke 1990, Roelke et al. 1991, Dunbar 1994, Barron et al. 2004); and Pteronura braziliensis (Gutleb et al. 1997, Fonseca et al. 2005).

The jaguar (Panthera onca) is the largest felid in the Neotropics, and the third largest worldwide (Hoogesteijn and Mondolfi 1992, Soisalo and Cavalcanti 2006, Campos Neto et al. 2011). Categorized as a Near Threatened species by the IUCN (Caso et al. 2008), the jaguar has historically ranged from the southwestern US through northern Argentina, with current range reduced by nearly 55\% (Sanderson et al. 2002, Caso et al. 2008). The Pantanal population is considered one of the remaining strongholds of wild jaguars, whose density ranges from $6.5-6.6$ individuals per 100 $\mathrm{km}^{2}$ (Soisalo and Cavalcanti 2006). The authors point out yet, that a large portion of the biome faces augmented anthropogenic pressures such as ranching, agriculture and development.

Previous studies have assessed the largescale environmental impacts of $\mathrm{Hg}$ in a variety of ecosystems, including in wetlands such as the Brazilian Pantanal (Hylander et al. 1994, 2000a, b, Callil and Junk 2001, Lacerda and Fitzgerald 2001, Leady and Gottgens 2001, Fonseca et al. 2005, Vieira et al. 2011, Alho and Sabino 2012). About 200 years before this present study, metallic $\mathrm{Hg}$ was introduced in the town of Poconé in the northern Pantanal (Mato Grosso state, Brazil), associated with gold mining activities to separate gold from ore (Callil and Junk 2001). Prior research indicates that the floral and faunal diversity of the Pantanal is severely threatened by anthropogenic activities, including $\mathrm{Hg}$ emissions from gold mining areas (Alho et al. 1988, Lacerda and Salomons 1998, Hylander et al. 2000b, Callil and Junk 2001, Leady and Gottgens 2001, Fonseca et al. 2005, Alho and Sabino 2012).

The prey base of jaguars includes over 85 species (Weckel et al. 2006), and includes aquatic mammalian, crocodilian, and fish species (Hayward 
et al. 2016). As apex predators, jaguars are at risk of accumulating high concentrations of pollutants that are biomagnified through the food chain. To our knowledge, only one other study examined $\mathrm{Hg}$ content in jaguars; concentrations from the teeth of two deceased individuals in Colombia were analyzed and found that concentrations were significantly lower than the minimum legal threshold (Racero-Casarrubia et al. 2012).

In the Brazilian Pantanal, jaguars may experience higher levels of $\mathrm{Hg}$ bioaccumulation and biomagnification as a result of extensive gold mining activities. Considering the toxic properties of $\mathrm{Hg}$ and its pervasive use at the upstream gold mining areas in the Pantanal floodplain, we hypothesize that $\mathrm{Hg}$ levels will be significantly higher in jaguars residing in the region of nearest proximity to gold mining operations, versus individuals residing in the site farther removed from the influence of gold mining.

\section{MATERIALS AND METHODS}

\section{STUDY SITES}

The Pantanal is a vast $140,000 \mathrm{~km}^{2}$ wetland located in central-western Brazil (Alho et al. 1988, Alho and Sabino 2012), where the elevation ranges from 50 to $150 \mathrm{~m}$ above sea level (Alho and Vieira 1997). Individual jaguars were captured in two areas in the Pantanal (Fig. 1). The first site, Fazenda São Bento - SB (17 20'35.79”S, 5643'39.33”W), is a privately owned cattle ranch and research headquarters located in the Itiquira River Basin (Mato Grosso state), $118.6 \mathrm{~km}$ downstream of Poconé (16 $16^{\circ} 1.97$ 'S, 56 $37^{\circ} 35.51$ ”W) in a region influenced by gold mining and $\mathrm{Hg}$ contamination. The second site, Refúgio Ecológico Caiman - CA (19 $57^{\prime} 15.58^{\prime \prime}$ 'S, 56 $\left.6^{\circ} 18^{\prime} 15.20^{\prime \prime} \mathrm{W}\right)$, is a privately-owned refuge dedicated to ecotourism and livestock use. Located in the Miranda River Basin (municipality of Miranda, Mato Grosso do Sul state), CA is a region free of gold mining activities, found $408.2 \mathrm{~km}$ from Poconé and 289.6 $\mathrm{km}$ from SB.

The Pantanal is characterized by distinct seasonality, with the rainy season averaging about $160 \mathrm{~mm}$ of rainfall per month (October - March) and dry season averaging $50 \mathrm{~mm}$ of rainfall per month (April - September; Soisalo and Cavalcanti 2006). The seasonal nature of the Pantanal has significant impact on floral and faunal life, where water levels can rise by up to $5 \mathrm{~m}$ (Junk and da Silva 1995, Gottgens et al. 2001), with maximum inundation in March and minimum in October (Hamilton et al. 1996, Guimarães et al. 2000).

The wetland is comprised of three distinct regions: the high (Alto); middle (Medio); and low (Baixo) (Hamilton et al. 1996, Guimarães et al. 2000). The Alto Pantanal possesses numerous veins of gold within clay layers; as a result, about 60 gold mining sites operate within this region alone (Nogueira et al. 1997, Hylander et al. 2000b). During extraction of gold from the clay $\mathrm{Hg}$ is used as an amalgamating agent, which results in $\mathrm{Hg}$ losses to the air, soil and water (Hylander et al. 1994, 2000b, Alho and Vieira 1997, Guimarães et al. 1998, 1999, Lacerda and Salomons 1998, Leady and Gottgens 2001). These losses impact the environment on local and regional scales, due to the elevated levels of $\mathrm{Hg}$ contamination in water and sediments (Alho and Vieira 1997, Lacerda and Salomons 1998, Guimarães et al. 1999, Callil and Junk 2001, Leady and Gottgens 2001, Alho and Sabino 2012).

\section{DATA COLLECTION}

Individual jaguars were captured using soft-hold foot-snares (Balme et al. 2007). The captures occurred in June 2013 in SB and in April through October 2013 in CA, during optimal dry season conditions. We monitored the snares every two hours through very high frequency (VHF) transmitters, with snares operational from $6: 00 \mathrm{pm}$ 


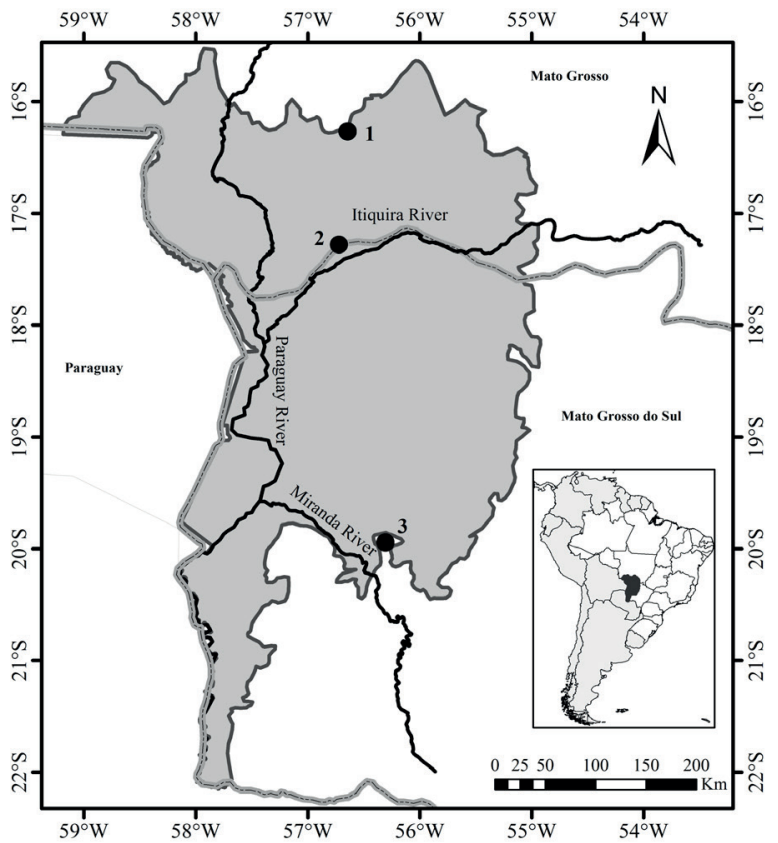

Figure 1 - Pantanal floodplain located in central-western Brazil, with the capture and gold mining sites, indicated by point location. Here, 1 - municipality of Poconé, Mato Grosso state (16 ${ }^{\circ} 16^{\prime} 1.97^{\prime}$ 'S, 56 37'35.51'W); 2 - Fazenda São Bento (17²0'35.79'’S, 5643'39.33”W); 3 - Refúgio Ecológico Caiman (19 $\left.57^{\circ} 15.58^{\prime \prime S}, 56^{\circ} 18^{\prime} 15.20^{\prime \prime} \mathrm{W}\right)$, municipality of Miranda, Mato Grosso do Sul state.

to 7:00am. We immobilized the captured animals with a dissociative combination dosage of $5 \mathrm{mg} /$ $\mathrm{kg}$ tiletamine hydrochloride and zolazepam hydrochloride administered via a dart fired from a $\mathrm{CO}_{2}$ rifle. A unique identification number was assigned to each captured animal. Each individual was examined for general body condition, sex, weight, and age (adult $>2$ years; subadult; and juvenile) based on tooth wear. Fur samples were collected and stored in plastic bags. We performed animal handling and sample collection according to ethical procedures and animal welfare standards (Sikes et al. 2011), and in adherence to protocols of the Brazilian Environment Institute (ICMBIO; permit \#42093-1).

\section{MERCURY CONTENT ANALYSIS}

Fur samples were triple washed with a mixture of diethyl ether : propanone $(3: 1, \mathrm{v} / \mathrm{v})$, then submerged in a solution of $5 \% \operatorname{EDTA}(\mathrm{w} / \mathrm{v})$ for 1 hour to remove superficial grease and dust to avoid external metal contamination. The samples were rinsed twice in ultra-purified water in a Milli-Q system (18 M $\Omega$ $\mathrm{cm}$ resistivity, oven-dried for 20 hours at $80^{\circ} \mathrm{C}$, and then digested in a microwave oven. A mass of about $150 \mathrm{mg}$ was directly weighed in Teflon jars, and then combined with $6 \mathrm{ml}$ of nitric acid $\left(\mathrm{HNO}_{3}\right)$ subboiling bi-distilled and $2 \mathrm{ml}$ of hydrogen peroxide $\left(\mathrm{H}_{2} \mathrm{O}_{2}\right) . \mathrm{Hg}$ analysis was performed in triplicate, in the Laboratory of Mass and Atomic Spectrometry of Universidade Federal de Santa Catarina, using atomic fluorescence spectrometry coupled with chemical vapor generation (CVG AFS). Steam generation conditions were regulated to: $6 \%(\mathrm{v} / \mathrm{v})$ of $\mathrm{HCl} ; 4 \%$ (w/v) of $\mathrm{SnCl}_{2} ; 0.08 \%$ (w/v) of $\mathrm{KMnO}_{4}$; and $0.05 \%(\mathrm{v} / \mathrm{v})$ of defoamer. The accuracy of the methods was evaluated by analyzing one certified reference material (BCR-397 Human hair Community Bureau of Reference) and comparing using a t-test at $95 \%$ confidence level. The precision was evaluated using relative standard deviation of individual samples measured in triplicate.

STATISTICAL ANALYSIS (ANOVA)

We submitted the resulting $\mathrm{Hg}$ content values to the normality Shapiro-Wilk test and converted the data into base10 logarithmic scales in order to reach the normal range. The log-transformed data were used in a one-way analysis of variance (ANOVA) in program $\mathrm{R}$ ( $\mathrm{R}$ Core Team 2016). Results were considered significantly different at $p<0.05$, and are expressed in units of $\mu \mathrm{g} \mathrm{g}^{-1} \pm \mathrm{SD}$ in dry-weight basis.

\section{RESULTS}

We captured nine individual jaguars in the two study areas (Table I), with four in SB (3 adult males; 1 juvenile male), and five in CA (2 adult females; 2 subadult females; 1 adult male). Body mass averages were $102.5 \pm 10.6 \mathrm{~kg}(\mathrm{n}=2$ females $)$ 
and $100.5 \pm 16.9 \mathrm{~kg}(\mathrm{n}=4$ males $)$ for adult females and for adult males, respectively. The average value obtained for $\mathrm{Hg}$ in the reference sample BCR 397 Human hair was $11.9 \pm 0.2 \mu \mathrm{g} \mathrm{g}^{-1}$, which was not significantly different from the certified value of $12.0 \pm 0.5 \mu \mathrm{g} \mathrm{g}^{-1}$.

The CVG AFS measurements used to analyze the jaguar fur samples were determined satisfactory through external calibration with an aqueous standard (linear correlation coefficient, $\mathrm{R}>0.9999$ ). The analysis included reasonable precision as indicated by relative standard deviations (RSD) of less than $8 \%(n=3)$. The limit of detection (LOD) was defined as three times the standard deviation of ten measurements of the blank sample, divided by the slope of the calibration curve. Using an aliquot of $0.15 \mathrm{~g}$ dried jaguar fur sample digested in a 50$\mathrm{mL}$ final volume solution, we obtained an estimated LOD of $0.07 \mu \mathrm{g} \mathrm{g}^{-1}$. The limit of quantification (LOQ) was defined as 3.3 times the LOD. The LOQ was estimated at $0.23 \mu \mathrm{g} \mathrm{g}^{-1}$ and considered adequate for the fur samples.

The mean content of $\mathrm{Hg}$ in individual jaguar fur samples ( $\mathrm{n}=3$ per animal) varied widely among individuals from the SB site, ranging from $26.1 \pm$ $5.1 \mu \mathrm{g} \mathrm{g}^{-1}$ in a juvenile male, to $2,010.4 \pm 150.5 \mu \mathrm{g} \mathrm{g}^{-1}$.
The mean individual values in the CA site ranged from $11.3 \pm 2.4$ to $70.0 \pm 7.2 \mu \mathrm{g} \mathrm{g}^{-1}$ (Table I). The untransformed mean $\mathrm{Hg}$ content in jaguars from the SB area $\left(673.0 \pm 916.8 \mu \mathrm{g} \mathrm{g}^{-1}\right)$ was compared to jaguars from CA area (29.7 $\pm 23.1 \mu \mathrm{g} \mathrm{g}^{-1}$; Fig. 2). $\mathrm{Hg}$ concentrations were not normally distributed $\left(\right.$ Shapiro-Wilk p-value $\left.=1.989 \mathrm{e}^{-05}\right)$. The ANOVA was therefore performed on log-transformed data and indicated a significant difference between sites $(\mathrm{p}=0.03)$.

\section{DISCUSSION}

This is the first study to evaluate $\mathrm{Hg}$ content in jaguars from the Brazilian Pantanal, and the second to report $\mathrm{Hg}$ content for this species (RaceroCasarrubia et al. 2012). In the present study, results from the log-transformed one-way ANOVA indicate that the mean content of $\mathrm{Hg}$ in the fur of SB jaguars was significantly different from those in CA.

The SB site is in close proximity to the city of Poconé (linear distance of $118.6 \mathrm{~km}$ ), which has high levels of human activity - including historically intensive gold mining during the 1980s to 1990 s, through the present day. Nearly 2 tons of $\mathrm{Hg}$ are sequestered in gold mine deposits around

TABLE I

Biological data and $\mathrm{Hg}$ levels $\left(\mu \mathrm{g} \mathrm{g}^{-1} \mathrm{dry}\right.$ weight) in the fur of individual jaguars captured in two areas (SB; CA). Hg content is presented as mean $\pm \mathrm{SD}\left(\mu \mathrm{g} \mathrm{g}^{-1}\right)$.

\begin{tabular}{|c|c|c|c|c|c|c|}
\hline \multirow{2}{*}{ Animal ID } & \multirow{2}{*}{ Sex } & \multirow{2}{*}{ Age } & \multirow{2}{*}{ Weight (kg) } & \multirow{2}{*}{ Date of Capture } & \multicolumn{2}{|c|}{ Hg content $\left(\mu g g^{-1}\right)$} \\
\hline & & & & & SB & $\mathbf{C A}$ \\
\hline SB396 & Male & Adult & 105 & 90 June 2013 & $133.2 \pm 27.1$ & --- \\
\hline SB434 & Male & Juvenile & 10 & 19 June 2013 & $26.1 \pm 5.1$ & --- \\
\hline SB414 & Male & Adult & 106 & 20 June 2013 & $522.1 \pm 27.9$ & --- \\
\hline SB435 & Male & Adult & 76 & 21 June 2013 & $2010.4 \pm 150.5$ & --- \\
\hline CA432 & Female & Subadult & 61 & 14 April 2013 & --- & $70.3 \pm 7.2$ \\
\hline CA433 & Female & Adult & 95 & 16 April 2013 & --- & $20.5 \pm 2.9$ \\
\hline CA439 & Male & Adult & 115 & 18 October 2013 & --- & $11.3 \pm 2.4$ \\
\hline CA440 & Female & Adult & 110 & 21 October 2013 & --- & $25.8 \pm 6.3$ \\
\hline CA445 & Female & Subadult & 81 & 27 October 2013 & --- & $20.8 \pm 4.6$ \\
\hline
\end{tabular}

$\mathrm{SB}=$ Fazenda São Bento; $\mathrm{CA}=$ Refúgio Ecológico Caiman. 


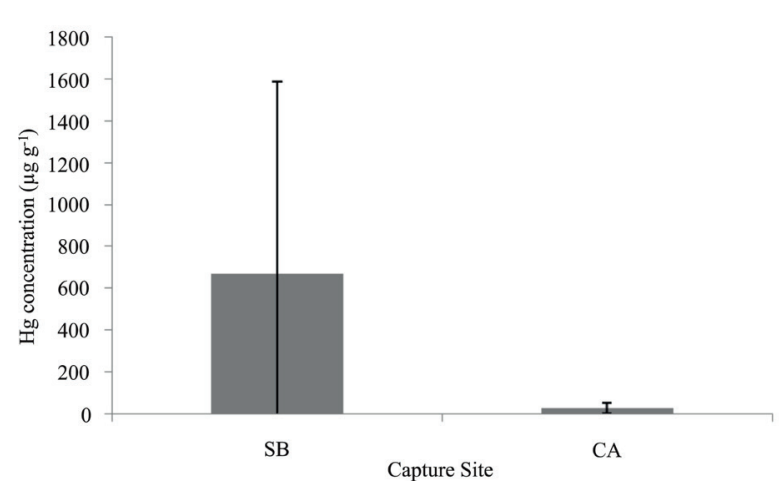

Figure 2 - Total $\mathrm{Hg}$ content $\left(\mu \mathrm{g} \mathrm{g}^{-1}\right.$ dry weight $\pm \mathrm{SD}$ ) in the fur of jaguars by capture site. Here, $\mathrm{SB}=$ Fazenda São Bento ( $\mathrm{n}=4$ individuals); $\mathrm{CA}=$ Refúgio Ecológico Caiman $(\mathrm{n}=5$ individuals).

the Poconé region (Lacerda et al. 1991a, Callil and Junk 2001). The process of amalgamation in gold mining results in environmental degradation ranging from the direct release of $\mathrm{Hg}$ into the water, and the erosion of riverbanks due to high-pressure water jets (Vieira et al. 2011). Rainfall, coupled with anthropogenically-induced high levels of erosion (e.g., agriculture; clear-cutting along riverbanks), causes $\mathrm{Hg}$ to percolate through the water table and into the lowland plateau (Hylander et al. 2000a). This percolation effect may result in the overall higher concentrations of $\mathrm{Hg}$ observed in the sampled individuals of SB versus CA. Although the CA study site is free from direct gold mining influence, we recorded $\mathrm{Hg}$ contents in the fur of jaguars that ranged from $11.3-70.3 \mu \mathrm{g} \mathrm{g}^{-1}$. This may be due to the latent percolation effects, where $\mathrm{Hg}$ is carried by floodwaters from the northern to the southern regions of the Pantanal.

Maximum concentrations of $\mathrm{Hg}$ were previously recorded in the teeth of jaguars in Colombia $\left(0.0887 \pm 0.013 \mu \mathrm{g} \mathrm{g}^{-1}\right.$ fresh weight; Racero-Casarrubia et al. 2012) and were considered below harmful biotic limits $\left(0.05 \mu \mathrm{g} \mathrm{g}^{-1}\right.$; Allen 1989, WHO 1991). As there is a current absence of further literature on $\mathrm{Hg}$ levels in jaguars, we draw further comparisons to a diverse base of existing studies which reported $\mathrm{Hg}$ concentrations in other mammalian species (Table II). For example, in North America, published studies of Puma c. coryi in the Everglades reported maximal $\mathrm{Hg}$ contents of $90 \mu \mathrm{g} \mathrm{g}^{-1}$ (fur) and $110 \mu \mathrm{g} \mathrm{g}^{-1}$ (liver) dry weights (Roelke 1990, Roelke et al. 1991, Dunbar 1994, Barron et al. 2004). The next highest recorded Hg value of $183 \mu \mathrm{g} \mathrm{g}^{-1}$ (fresh weight) was reported in the fur of L. canadensis (Sleeman et al. 2010). With a conversion of 3:1 of dry : wet weight (Puls 1994), the value detected by Sleeman et al. (2010) increases to $549 \mu \mathrm{g} \mathrm{g}^{-1}$. HgTot in human hair collected from villagers living near Poconé ranged from 0.3 to $3.11 \mu \mathrm{g} \mathrm{g}^{-1}$ (Nogueira et al. 1997). Such concentrations are in stark contrast to the World Health Organization $\mathrm{Hg}$ limit of $0.05 \mu \mathrm{g} \mathrm{g}^{-1}$ (Allen 1989, WHO 1991). Our data suggest that the $\mathrm{Hg}$ content in the fur of jaguars from SB is the highest ever recorded in wild mammals.

The food web within the Pantanal is complex and includes diverse communities of both aquatic and terrestrial biota (Junk et al. 2006). Aquatic predators can accumulate $\mathrm{Hg}$ through the consumption of contaminated prey (Callil and Junk 2001), resulting in high concentrations of $\mathrm{Hg}$ in the aquatic food chain (Leady and Gottgens 2001). Lacerda et al. (1991b) recorded Hg concentrations of about $0.91 \pm 0.06 \mu \mathrm{g} \mathrm{g}^{-1}$ in Pomacea caniculata near gold mines in the northern Pantanal. Within the same region, Callil and Junk (2001) recorded values as high as $2.04 \pm 1.27 \mu \mathrm{g} \mathrm{g}^{-1}$ of $\mathrm{Hg}$ in Pomacea scalaris. Hylander et al. (2000b) recorded total mercury (HgTot) content as high as $2.05 \mu \mathrm{g} \mathrm{g}^{-1}$ fresh weight in a predatory fish (Serrasalmus spp.) in a creek in Alto Pantanal, near Poconé, that ranged from 0.04 to $2.05 \mu \mathrm{g} \mathrm{g}^{-1}$ (fresh weight). High values of $\mathrm{Hg}$ were also detected in Serrasalmus spiropleura (0.15 $\mu \mathrm{g} \mathrm{g}^{-1}$; dry weight) and Pygocentris nattereri $\left(0.30 \mu \mathrm{g} \mathrm{g}^{-1}\right.$; dry weight $)$ from $\mathrm{Hg}$-impacted regions in the northern Pantanal (Leady and Gottgens 2001). 
TABLE II

\begin{tabular}{|c|c|c|c|c|c|}
\hline \multirow{2}{*}{ Species } & \multirow{2}{*}{ Location } & \multirow{2}{*}{ Tissue } & \multicolumn{2}{|c|}{ Maximal Content $\left(\mu \mathrm{g} \mathrm{g}^{-1}\right)$} & \multirow{2}{*}{ Reference } \\
\hline & & & Dry Weight & Wet Weight & \\
\hline \multirow[t]{5}{*}{ N. vison } & Saskatoon, Canada & Liver & 58.2 & --- & Wobeser and Swift (1976) \\
\hline & & Kidney & 34.9 & --- & \\
\hline & & Fur & 31.9 & --- & \\
\hline & & Muscle & 15.2 & --- & \\
\hline & & Brain & 13.4 & --- & \\
\hline \multirow[t]{4}{*}{ L. canadensis } & Ontario, Canada & Liver & 96.0 & --- & Wren (1985) \\
\hline & & Kidney & 58.0 & --- & \\
\hline & & Muscle & 36.0 & --- & \\
\hline & & Brain & 30.0 & --- & \\
\hline \multirow[t]{2}{*}{ P. c. coryi } & Florida, USA & Liver & --- & 110 & Dunbar (1994) \\
\hline & & Fur & --- & 90.0 & \\
\hline \multirow[t]{4}{*}{ P. Braziliensis } & Brazilian Pantanal & Kidney & --- & 4.59 & Fonseca et al. (2005) \\
\hline & & Liver & --- & 4.30 & \\
\hline & & Fur & --- & 3.68 & \\
\hline & & Muscle & --- & 0.17 & \\
\hline \multirow[t]{5}{*}{ L. canadensis } & Virginia, USA & Kidney & 353.0 & --- & Sleeman et al. (2010) \\
\hline & & Liver & 221.0 & --- & \\
\hline & & Fur & --- & 183.0 & \\
\hline & & Brain & 151.0 & --- & \\
\hline & & Muscle & 121.0 & --- & \\
\hline P. onca & Colombia & Teeth & --- & 0.0887 & Racero-Casarrubia et al. (2012) \\
\hline P. onca & Brazilian Pantanal & Fur & $2,010.04$ & --- & Present study \\
\hline
\end{tabular}

$\mathrm{Hg}$ has also been reported in crocodilian species (Yanochko et al. 1997, Elsey et al. 1999, Burger et al. 2000, Rumbold et al. 2002), including Caiman c. yacare from areas of intensive human activity in the Brazilian Pantanal (0.02 to 0.36 $\mu \mathrm{g}^{-1}$ wet weight; Vieira et al. 2011). The relatively high $\mathrm{Hg}$ values recorded in different levels of the ecosystem corroborate the presence of an elevated rate of biomagnification in the $\mathrm{Hg}$-impacted Pantanal region.

Previous research indicates that fish and apex predators within the aquatic community tend to store $\mathrm{Hg}$ in readily-digestible muscle, whereas avian and mammalian species store $\mathrm{Hg}$ in feathers and fur (Hylander et al. 2000b, Leady and Gottgens 2001, Risher et al. 2002, Davis et al. 2003). The accumulation of $\mathrm{Hg}$ within the food chain is greatest in long-lived, apex species (Roelke 1991, Callil and Junk 2001, Leady and Gottgens 2001, Chan et al. 2003). Jaguars are generally opportunistic top predators with flexible diets (Emmons 1987, Cavalcanti and Gese 2010, Da Silveira et al. 2010), and will often prey upon Hydrochaeris hydrochaeris and Caiman c. yacare when available, but will also consume small $(<1$ $\mathrm{kg}$ ), medium (1-15 kg), and large terrestrial prey (>15 kg; Polisar et al. 2003, Weckel et al. 2006, Azevedo and Murray 2007, Da Silveira et al. 2010, Perilli et al. 2016).

With the Brazilian Pantanal's remarkable biodiversity, complex food web, and human population that relies on high per capita fish 
consumption, understanding $\mathrm{Hg}$ dynamics and the risks of exposure is therefore particularly urgent (Leady and Gottgens 2001) for informing wildlife conservation plans and human health programs in the greater Pantanal region. The jaguar may serve as a useful indicator species for the continued monitoring of $\mathrm{Hg}$ concentrations within this environment.

\section{CONCLUSIONS}

Contamination of $\mathrm{Hg}$ in the biotic and abiotic factors of the ecosystem is well documented in the Brazilian Pantanal, and appears to bioaccumulate through aquatic, carnivorous links in the food web. With the highest body burdens observed in jaguars from the northern Pantanal region of SB, where gold mining activities were most intensive, our data suggest that the $\mathrm{Hg}$ content in an individual jaguar from the Brazilian Pantanal is the highest ever recorded in wild animals. Chronic exposure of jaguars to $\mathrm{Hg}$ may potentially compromise relative individual health and productivity. Thus, $\mathrm{Hg}$ should be considered a threat to this key species. The jaguar may serve as a sentinel species for short- and long-term study and monitoring. Further research is needed to further quantify the degree of $\mathrm{Hg}$ contamination within the greater Pantanal region.

\section{ACKNOWLEDGMENTS}

The authors thank Tetra Pak Ltda. (Brazil), Global Insular Conservation Society (GICS), Panthera, Projeto Onçafari and ICMBio/CENAP for financial support, and professors Nicole R. Hlavac and Vinícius C. Tabeleão for valuable suggestions on a first draft of the manuscript.

\section{REFERENCES}

AKIRA Y, MIYUKI M, MASAKO Y AND NORIYUKI H. 2004. Current hair mercury levels in Japanese for estimation of methylmercury exposure. J Health Sci 50: 120-125.
ALHO CJR AND SABINO J. 2012. Seasonal Pantanal flood pulse: implications for biodiversity conservation - a review. Oecologia Australis 16: 958-978.

ALHO CJR AND VIEIRA LM. 1997. Fish and wildlife resources in the Pantanal wetlands of Brazil and potential disturbances from the release of environmental contaminants. Environ Toxicol Chem 16: 71-74.

ALHO CJR, LACHER TE AND GONÇALVES HC. 1988. Environmental degradation in the Pantanal ecosystem. Bioscience 38: 164-171.

ALLEN SE. 1989. Chemical analysis of ecological materials, $2^{\text {nd }}$ ed., London: Blackwell Scientific Publications, 380 p.

AZEVEDO FCC AND MURRAY DL. 2007. Spatial organization and food habits of jaguars (Panthera onca) in a floodplain forest. Biol Conserv 137: 391-402.

BALME GA, HUNTER LTB AND SLOTOW R. 2007. Feeding habitat selection by hunting leopards in a woodland savanna: prey catchability versus abundance. Anim Behav 74: 589-598.

BARRON MG, DUVALL SE AND BARRON KJ. 2004. Retrospective and current risks of mercury to panthers in the Florida Everglades. Ecotoxicology 13: 223-229.

BASU N, SCHEUHAMMER AM, BURSIAN SJ, ELLIOTT J, ROUVINEN-WATT K AND CHAN HM. 2007. Mink as a sentinel species in environmental health. Environ Res 103: 130-144.

BURGER J, GOCHFELD M, ROONEY AA, ORLANDO EF, WOODWARD AR AND GUILLETTE LJ. 2000. Metal and metalloids in tissues of American alligators in three Florida lakes. Arch Environ Con Tox 38: 501-508.

CALLIL CT AND JUNK WJ. 2001. Aquatic gastropods as mercury indicators in the Pantanal of Poconé region (Mato Grosso, Brazil). Water Air Soil Poll 125: 319-330.

CAMPOS NETO MF, GARRONE NETO D AND HADDAD JR V. 2011. Attacks by jaguars (Panthera onca) on humans in central Brazil: report of three cases, with observation of a death. Wild Environ Med 22: 130-135.

CASO A, LOPEZ-GONZALEZ C, PAYAN E, EIZIRIK E, DE OLIVEIRA T, LEITE-PITMAN R, KELLY M AND VALDERRAMA C. 2008. Panthera onca. The IUCN Red List of Threatened Species 2008.e.T15953A5327466. Version 2016.3. http://dx.doi.org/10.2305/IUCN.UK.2008. RLTS.T15953A5327466.en.

CAVALCANTI SMC AND GESE EM. 2010. Kill rates and predation patterns of jaguars (Panthera onca) in the southern Pantanal, Brazil. J Mammal 91: 722-736.

CHAN HM, SCHEUHAMMER AM, FERRAN A, LOUPELL, C, HOLLOWAY J AND WEECH S. 2003. Impacts of mercury on freshwater fish-eating wildlife and humans. Hum Ecol Risk Assess 9: 867-883.

DA SILVEIRA R, RAMALHO EE, THORBJARNARSON JB AND MAGNUSSON WE. 2010. Depredation by jaguars 
on caimans and importance of reptiles in the diet of jaguar. J Herpetol 44: 418-424.

DAVIS JA, YEE D, COLLINS JN, SCHWARZBACH SE AND LUOMA SM. 2003. Potential for increased mercury accumulation in the estuary food web. In: Brown LR (Ed), Issues in San Francisco Estuary Tidal Wetlands Restoration. San Francisco Estuary and Watershed Science 1: 1-36.

DUNBAR MR. 1994. Florida panther biomedical investigation. Final Performance Report, Statewide Wildlife Research, Study 7506. Gainesville: Florida Game and Fresh Water Fish Commission, $54 \mathrm{p}$.

EHRLICH HL and NEWMAN DK. 2008. Geomicrobiology, $5^{\text {th }}$ ed., Boca Raton: CRC Press, 628 p.

ELSEY RM, LANCE VA and CAMPBELL L. 1999. Mercury levels in alligator meat in south Louisiana. B Environ Contam Tox 63: 598-603.

EMMONS LH. 1987. Comparative feeding ecology of felids in a Neotropical rainforest. Behav Ecol Sociobiol 20: 271283.

EVANS RD, ADDISON EM, VILLENEUVE JY, MACDONALD KS and JOACHIM DG. 1998. An examination of spatial variation in mercury concentrations in otter (Lutra canadensis) in south-central Ontario. Sci Total Environ 213: 239-245.

EVANS RD, ADDISON EM, VILLENEUVE JY, MACDONALD KS and JOACHIM DG. 2000. Distribution of inorganic and methylmercury among tissues in mink (Mustela vison) and otter (Lutra canadensis). Environ Res 84: 133-139.

FONSECA FRD, MALM O and WALDEMARIN HF. 2005. Mercury levels in tissues of Giant otters (Pteronura Braziliensis) from the Rio Negro, Pantanal, Brazil. Environ Res 98: 368-371.

GOTTGENS JF, PERRY JE, FORTNEY RH, MEYER JE, BENEDICT M AND ROOD BE. 2001. The ParaguayParaná Hidrovia: Protecting the Pantanal with Lessons from the Past. Bioscience 51: 301-308.

GUIMARÃES JRD, MEILI M, MALM O AND BRITO EM. 1998. Hg methylation in sediments and floating meadows of a tropical lake in the Pantanal floodplain, Brazil. Sci Total Environ 213: 165-175.

GUIMARÃES JRD, FOSTIER AH, FORTI MC, MELFI JA, HERIG H, MAURO JBN, MALM O AND RUG JF. 1999. Mercury in human and environmental samples from two lakes in Amapá, Brazilian Amazon. Ambio 28: 296-301.

GUIMARÃES JRD, MARKUS M, HYLANDER LD, SILVA EC, ROULETE M, NARVAEZ M AND LEMOS RA. 2000. Mercury net methylation in five tropical flood plain regions of Brazil: high in the root zone of floating macrophyte mats but low in surface sediments and flooded soils. Sci Total Environ 261: 99-107.
GUTLEB AC, SCHENCK C AND STAIB E. 1997. Giant otter (Pteronura Braziliensis) at risk? Total mercury and methylmercury levels in fish and otter scats Peru. Ambio 26: 511-514.

HALBROOK RS, JENKINS JH, BUSH PB AND SEABOLT ND. 1994. Sublethal concentrations of mercury in river otters: monitoring environmental contamination. Arch Environ Cont Tox 27: 306-310.

HAMILTON SK, SIPPEL SJ AND MELACK JM. 1996. Inundation patterns in the Pantanal wetland of South America determined from passive microwave remote sensing. Arch Hydrobiol 137: 1-23.

HAYWARD, MW, KAMLER JF, MONTGOMERY RA, NEWLOVE A, ROSTRO-GARCIA S, SALES LP AND VAN VALKENBURGH B. 2016. Prey preferences of the jaguar Panthera onca reflect the post-Pleistocene demise of large prey. Front Ecol Evol 3: https://doi.org/10.3389/ fevo.2015.00148.

HOOGESTEIJN R AND MONDOLFI E. 1992. El Jaguar: Tigre Americano. Caracas: Armitano Editores, 182 p.

HYLANDER LD, SILVA EC, OLIVEIRA LJ, SILVA SA, KUNTZE EK AND SILVA DX. 1994. Mercury levels in Alto Pantanal - a screening study. Ambio 23: 478-484.

HYLANDER LD, MEILI M, OLIVEIRA LJ, DE CASTRO E SILVA E, GUIMARÃES JR, ARAÚJO DM, NEVES RP, STACHIW R, BARROS AJ AND SILVA GD. 2000a. Relationship of mercury with aluminum, iron and manganese oxyhydroxides in sediments from the Alto Pantanal, Brazil. Sci Total Environ 260: 97-107.

HYLANDER LD, PINTO FN, GUIMARÃES JR, MEILI M, OLIVEIRA LJ AND DE CASTRO E SILVA E. 2000b. Fish mercury concentration in the Alto Pantanal, Brazil: influence of season and water parameters. Sci Total Environ 261: 9-20.

HYVÄRINEN H, TYNI P AND NIEMINEN P. 2003. Effects of moult, age, and sex on the accumulation of heavy metals in the otter (Lutra lutra) in Finland. B Environ Contam Tox 70: 278-284.

JUNK WJ AND DA SILVA CJ. 1995. Neotropical floodplains: a comparison between the Pantanal of Mato Grosso and the large Amazonian river floodplains. In: Tundisi JG, Bicudo CE and Tundisi TM (Eds), Limnology in Brazil, Rio de Janeiro: Academia Brasileira de Ciências, Sociedade Brasileira de Limnologia, p. 195-217.

JUNK WJ, CUNHA CN, WANTZEN KM, PETERMANN P, STRÜSSMANN C, MARQUES MI AND ADIS J. 2006. Biodiversity and its conservation in the Pantanal of Mato Grosso, Brazil. Aquat Sci 68: 278-309.

KIRBY A, RUCEVSKA I, YEMELIN V, COOKE C, SIMONETT O, NOVIKOV V AND HUGHES G. 2013. Mercury - time to act. Geneva: United Nations Environment Programme - UNEP, 42 p. 
LACERDA LD AND FITZGERALD WF. 2001. Biogeochemistry of mercury in wetlands. Wetl Ecol Manag 9: 291-293.

LACERDA LD, PFEIFFER WC AND BASTOS WR. 1991a. Mercury dispersal in the Poconé region, Mato Grosso State, Central Brazil. Ciência e Cultura (SBPC) 43: $317-$ 320.

LACERDA LD AND SALOMONS W. 1998. Mercury from gold and silver mining. A chemical time-bomb? Berlin: Springer Science \& Business Media, $147 \mathrm{p}$.

LACERDA LD, SALOMONS W, PFEIFFER WC AND BASTOS WR. 1991b. Mercury distribution in sediment profiles of remote high Pantanal lakes, central Brazil. Biogeochemistry 14: 71-77.

LEADY BS AND GOTTGENS JF. 2001. Mercury accumulation in sediment cores and along food chains in two regions of the Brazilian Pantanal. Wetl Ecol Manag 9: $349-361$.

MASON CF. 1988. Concentrations of organochlorine residues and metals in tissues of otters Lutra lutra from the British Isles, 1985-1986. Lutra 31: 62-67.

MASON CF AND MADSEN AB. 1992. Mercury in Danish otters (Lutra lutra). Chemosphere 25: 865-867.

NOGUEIRA F, NASCIMENTO OC, SILVA EC AND JUNK W. 1997. Mercúrio total em cabelos: uma contribuição para se avaliar o nível de exposição em Poconé, Mato Grosso, Brazil. Cad Saúde Públ 13: 601-609.

NUTTALL KL. 2006. Interpreting hair mercury levels in individual patients. Ann Clin Lab Sci 36: 248-261.

PERILLI MLL, LIMA F, RODRIGUES FHG AND CAVALCANTI SMC. 2016. Can scat analysis describe the feeding habits of big cats? A case study with jaguars (Panthera onca) in southern Pantanal, Brazil. PloS ONE 11: $1-12$.

POLISAR J, MAXIT I, SCOGNAMILLO D, FARRELL L, SUNQUIST ME AND EISENBERG JF. 2003. Jaguars, pumas, their prey base, and cattle ranching: ecological interpretations of a management problem. Biol Conserv 109: 297-310.

PULS R. 1994. Mineral levels in animal health: diagnostic data, $2^{\text {nd }}$ ed., Clearbrook, BC, Canada: Sherpa International, $356 \mathrm{p}$.

R CORE TEAM. 2016. R: a language and environment for statistical computing. Vienna: R Foundation for Statistical Computing.

RACERO-CASARRUBIA JA, MARRUGO-NEGRETE JL AND PINEDO HERNÁNDEZ JJ. 2012. Hallazgo de mercurio en piezas dentales de Jaguares (Panthera onca) provenientes de la zona amortiguadora del Parque Nacional Natural Paramillo, Córdoba, Colombia. RLC 2-3: 87-92.

RISHER JF, MURRAY HE AND PRINCE GR. 2002. Organic mercury compounds: human exposure and its relevance to public health. Toxicol Ind Health 18: 109-160.
ROELKE ME 1990. Florida panther biomedical investigation: health and reproduction. Final performance report, July1, 1986 to June 30, 1990, study no. 7506. Tallahassee: Florida Game and Fresh Water Fish Commission, 176 p.

ROELKE ME. 1991. Florida panther biomedical investigation. Annual performance report, July 1, 1990 to June 30, 1991, study no. 7506. Gainesville: Florida Game and Fresh Water Fish Commission, 91 p.

ROELKE ME, SCHULZ DP, FACEMIRE CF, SUNDLOF SF AND ROYALS HE. 1991. Mercury contamination in Florida panthers. Tallahassee: Florida Panther Technical Subcommittee, Florida Game and Fresh Water Fish Commission, $50 \mathrm{p}$.

RUMBOLD DG, FINK LE, LAINE KA, NIEMCZYK SL, CHANDRASEKHAR T, WANKEL SD AND KENDALL C. 2002. Levels of mercury in alligators (Alligator mississippiensis) collected along a transect through the Florida Everglades. Sci Total Environ 297: 239-252.

SANDERSON EW, REDFORD KH, CHETKIEWICZ CB, MEDELLIN RA, RABINOWITZ AR, ROBINSON JG AND TABER AB. 2002. Planning to save a species: the jaguar as a model. Conserv Biol 16: 8-62.

SIKES RS, GANNON WL AND THE ANIMAL CARE AND USE COMMITTEE OF THE AMERICAN SOCIETY OF MAMMALOGISTS. 2011. Guidelines of the American Society of Mammalogists for the use of wild mammals in research. J Mammal 92: 235-253.

SLEEMAN JM, CRISTOL DA, WHITE AE, EVERS DC, GERHOLD RW AND KEEL MK, 2010. Mercury poisoning in a free-living northern river otter (Lontra canadensis). J Wildlife Dis 46: 1035-1039.

SOISALO M AND CAVALCANTI S. 2006. Estimating the density of a jaguar population in the Brazilian Pantanal using camera traps and capture-recapture sampling in combination with GPS radio-telemetry. Biol Conserv 129: 487-496.

VIEIRA LM, NUNES V DA S, AMARAL MC DO A, OLIVEIRA AC, HAUSER-DAVIS RA AND CAMPOS RC. 2011. Mercury and methyl mercury ratios in caimans (Caiman crocodilus yacare) from the Pantanal area, Brazil. J Environ Monitor 13: 280-287.

WECKEL M, GIULIANO W AND SILVER S. 2006. Jaguar (Panthera onca) feeding ecology: distribution of predator and prey through time and space. J Zool 270: 25-30.

WHO. 1991. Inorganic Mercury. Environmental Health Criteria 118, n. 107. Geneva: World Health Organization. http://www.inchem.org/documents/ehc/ehc/ehc118.htm.

WOBESER G, NIELSEN NO AND SCHIEFER B. 1976. Mercury and mink. II. Experimental methyl mercury intoxication. Can J Comp Med 40: 34-45.

WOBESER G AND SWIFT M. 1976. Mercury poisoning in a wild mink. J Wildlife Dis 12: 335-340. 
WREN CD. 1985. Probable case of mercury poisoning in wild otter, Lutra canadensis, in northwestern Ontario. Can Field Nat 99: 112-114.

WREN CD, STOKES PM AND FISCHER KL. 1986. Mercury levels in Ontario mink and otter relative to food levels and environmental acidification. Can J Zool 64: 2854-2859.

YANOCHKO GM, JAGOE CH AND BRISBIN JR IL. 1997. Tissue mercury concentrations in alligators (Alligator mississippiensis) from the Florida Everglades and the Savannah River Site, South Carolina. Arch Environ Con Tox 32: 323-328.

YATES DE, MAYACK DT, MUNNEY K, EVERS DC, MAJOR A, KAUR T AND TAYLOR RJ. 2005. Mercury levels in mink (Mustela vison) and river otter (Lontra canadensis) from Northeastern North America. Ecotoxicology 14: 263 274. 